\section{Using a Case Approach to Assess Farmers' Attitudes Regarding Central Terminal Model Electronic Benefits Transfer (EBT) Programs at Selected Michigan Farmers Markets}

\author{
Dru N. Montri ${ }^{1,4}$, Bridget K. Behe ${ }^{2}$, and Kimberly Chung ${ }^{3}$
}

ADDITIONAL INDEX wORDs. direct marketing, interviews, Supplemental Nutrition Assistance Program, food stamps, farmers' attitudes

SummarY. Recently, the U.S. Department of Agriculture (USDA) has pushed to increase the number of farmers markets that accept Supplemental Nutrition Assistance Program (SNAP) benefits (formerly known as food stamps) via Electronic Benefits Transfer (EBT). However, a small percentage of farmers markets accept SNAP and little is known of the experience of the farmer-vendors who participate in central terminal model EBT programs at farmers markets. The objective of this exploratory study was to elucidate farmers' attitudes regarding central terminal model EBT programs at selected Michigan farmers markets. This study used qualitative research methods and a case approach. Thirty-two farmers that participated in central terminal model EBT programs at farmers markets were interviewed. Three main themes emerged. First, based on their experiences, farmers expressed a positive attitude toward central terminal model EBT programs at farmers markets. Second, positive attitudes were often associated with the view that market managers had made it easy for farmers to accept EBT benefits and freed them from the administrative burdens of redemption and federal reporting. Third, farmers believed that accepting food assistance benefits attracted new customers to the farmers market thus expanding their customer base. While these results may not be reflective of farmers' attitudes in other regions, the themes that emerged highlight topics that may be important considerations when making future decisions about the expansion of electronic food assistance programs at farmers markets.

A farmers market is a public and recurring assembly of farmers or their representatives who sell food or agricultural products they produce directly to consumers. In addition, farmers markets may include a variety of other vendors as determined by market management [Michigan Farmers Market Association (MIFMA), 2012a]. Farmers markets are credited with providing a range of benefits from promoting small and midsized farm viability to strengthening communities (Abel et al., 1999; Ross, 2006).

The authors gratefully acknowledge the North Central Region (NCR) Sustainable Agriculture Research and Education (SARE) Graduate Student Grant Program for funding this research.

${ }^{1}$ Department of Horticulture and Department of Community, Agriculture, Recreation and Resource Studies, Michigan State University, 480 Wilson Road, Room 172D Natural Resources Building, East Lansing, MI 48824

${ }^{2}$ Professor, Department of Horticulture, Michigan State University, 1066 Bogue Street, Room A238 Plant and Soil Science Building, East Lansing, MI 48824

${ }^{3}$ Associate Professor, Department of Community, Agriculture, Recreation and Resource Studies, Michigan State University, 480 Wilson Road, Room 317 Natural Resources Building, East Lansing, MI 48824

${ }^{4}$ Corresponding author. E-mail: dnmontri@msu.edu.
Considering these benefits and the growing popularity of locally grown foods (Keeling-Bond et al., 2009; Zepeda and $\mathrm{Li}, 2006$ ), the increase in the number of farmers markets across the country is not surprising (1755 in 1994 to 7175 in 2011 ) (USDA, 2012a). The trend is similar in Michigan with the number of farmers markets growing from 90 in 2001 to more than 300 in 2012 (MIFMA, 2012b).

Many new farmers markets are located in low-income communities where residents do not have easy access to fresh and healthy foods. Limited access to nutritious food may be linked to poor diets, increases in obesity, and diet-related diseases (USDA, 2009). However, recent evidence suggests that when low-income individuals have access to retail outlets that provide affordable, nutritious foods, they make healthier food choices and have better health outcomes (Flournoy, 2011). Food security researchers and advocates argue that farmers markets are needed most in these communities as they provide access to nutritious foods that are not available otherwise (Bell and Standish, 2009; Pothukuchi and Thomas, 2004).

Farmers markets, however, are especially vulnerable to failure in lowincome communities and therefore present a number of challenges (Fisher, 1999; Project for Public Spaces, 2003). Markets in low-income areas often struggle with high farmer and vendor turnover rates and a general lack of vendor commitment (Alkon, 2008; Fisher, 1999). Fisher (1999) concluded that for farmers markets in low-income areas to be successful, farmers must provide an appropriate mix of product at affordable prices. However, he also noted a "fundamental tension" between farmers earning a fair price and the ability of low-income shoppers to pay such prices. Alkon (2008) reported that the need for farmers to earn a fair price can and sometimes does conflict with a market's goal to improve food access for low-income shoppers. Thus, to address the need of farmers to earn adequate revenue at farmers markets, market organizers continually seek ways to expand a market's customer base and increase sales. Recent research indicated that the number of customers had a significant positive influence on vendor participation in farmers markets (Hofmann et al., 2009).

One way to increase the customer base is to introduce new populations, such as food assistance program recipients, to the farmers market. Supplemental Nutrition Assistance Program recipients can purchase food at farmers markets if EBT is available. EBT is a system that allows recipients of federal food assistance programs to purchase food from an authorized retailer using a benefits card. An EBT card works like a debit card and allows recipients to authorize the transfer of their food assistance benefits from a

\begin{tabular}{llll}
\hline $\begin{array}{l}\text { Units } \\
\begin{array}{l}\text { To convert U.S. to SI, } \\
\text { multiply by }\end{array}\end{array}$ & U.S. unit & SI unit & $\begin{array}{l}\text { To convert SI to U.S., } \\
\text { multiply by }\end{array}$ \\
\hline 0.4047 & acre $(\mathrm{s})$ & $\mathrm{ha}$ & 2.4711 \\
0.0929 & $\mathrm{ft}^{2}$ & $\mathrm{~m}^{2}$ & 10.7639
\end{tabular}


federal account to a retailer's account, such as a farmers market or grocery store (Montri et al., 2011). The total value of SNAP sales offers significant revenue to food retailers. In Michigan, for example, SNAP brings $\$ 245.6$ million of food sales to the state each month (State of Michigan, 2012). In the United States, 44.7 million people, or $13 \%$ of the population, used EBT in 2011 to redeem $\$ 71.8$ billion worth of SNAP benefits (USDA, $2012 b)$. SNAP-eligible food items include food or food products for human use such as breads, meat, dairy products, cereals, seeds, fruit, vegetables, and plants or seeds for use in a home garden to produce food for personal use (USDA, 2012c).

In the past, food stamps were widely accepted in farmers markets. However, most farmers markets discontinued accepting food stamps when the program transitioned to EBT since they were no longer able to accept paper coupons (USDA, 2010a). Instead, EBT requires a point of sale device (POSD) to accept food assistance benefits as payment. Since farmers markets typically operate in temporary or open-air venues, they often lack the infrastructure needed to support a POSD. Recent evidence suggests that many vendors are now dissuaded from accepting SNAP/ EBT because of the cost and administrative burdens of purchasing and operating a wireless POSD (MIFMA, unpublished data). As such, food stamp redemptions dropped dramatically in farmers markets between the early 1990s and mid-2000s when the program transitioned to EBT (USDA, 2010a).

A central terminal model EBT program at farmers markets, however, can alleviate much of the burden for individual vendors, increasing their sales especially among clientele who might not otherwise afford fresh produce. Under a centralized system, markets provide a central POSD to accept benefits from all SNAP shoppers. The POSD deducts food assistance benefits from a shopper's EBT card and in exchange the market issues an equal value in alternative market currency, usually a wooden nickel or paper scrip, that the shopper may use to purchase eligible items from any vendor at the market. Vendors accept the alternative currency like cash and are later reimbursed by the market.
Under this system, the market takes responsibility for the costs of operating the POSD and for complying with federal requirements to account for the distribution of federal food assistance benefits. The market also assumes responsibility to reimburse the vendor for their EBT sales occurring at the market (Montri et al., 2011).

Despite growing interest in expanding the number of farmers markets accepting EBT (Buttenheim et al., 2012), little is known about the experience of EBT from the perspective of the actors who implement these programs at farmers markets. The peer reviewed literature on farmers markets has primarily focused on consumer access, nutrition education, and consumer participation in food assistance programs (Anliker et al., 1992; Balsam et al., 1994; Dollahite et al., 2005; Just and Weninger, 1997). At the practitioner level, market organizers and agricultural educators have published how-to guides and case study reports on EBT programs (e.g., Montri et al., 2011; Wasserman et al., 2010). Mino (2012) reported that the administrative burdens of implementing these programs are significant and suggested that not all farmers markets may be candidates for EBT. Yet, the literature offers nothing about farmer experiences with EBT programs at farmers markets. Like market staff, farmers are intimately involved in the EBT redemption process and as vendors they are necessary for the program to function. What is their experience and how does it affect the market?

Accordingly, the objective of this study was to use a case study approach to explore farmers' attitudes regarding central terminal model EBT programs at selected Michigan farmers markets. Michigan is an appropriate site for this work because, in contrast to most states, there is now substantial experience with EBT at Michigan farmers markets. In 2006, only three Michigan farmers markets were authorized to accept EBT. In 2012, more than 100 farmers markets accepted EBT. Currently, Michigan leads the midwestern United States and ranks third nationwide in the number of farmers markets authorized to accept EBT (Roper, 2012). The majority of these farmers markets (77 of 78 in 2011) use a central terminal model (Segar, 2012). EBT redemptions at Michigan farmers markets have increased exponentially from $\$ 15,832$ in 2007 to $\$ 898,194$ in 2011 (Segar, 2012), and Michigan is now fourth in the nation in the total EBT sales that take place at farmers markets (Roper, 2012). As such, Michigan farmers are increasingly familiar with and have experience with EBT redemption at multiple markets.

As a case study, the intention of this work is not to generalize from a sample to the population, but to identify emergent themes that may be important to current efforts to expand EBT programs at farmers markets and for future research. These themes may then be subsequently investigated using sample surveys and appropriate hypothesis testing. Case study sampling does not allow generalization to the larger population of farmers markets or farmer-vendors across the region or country. However, the research design purposely samples across a wide range of farmer experiences. Gaining a better understanding of farmer perceptions and preferences will help researchers and practitioners develop further research, policies, and programs that will work for farmers. Doing so will help improve the functioning of EBT programs at markets and the retention of farmer-vendors at low-income farmers markets. In addition, given that farmers markets are venues for the sale of horticultural products, this work also supports the overall sustainability and profitability of the horticultural industry.

\section{Methods}

This study used a qualitative, case study approach. Qualitative work is suitable for topics in which little is currently known and thus seeks to understand insider' perspectives on what is most important (Maxwell, 2012). This research methodology seeks rich data, characterized by depth and detail, as a means to develop an emergent theory informed by the perspectives of those involved in the phenomenon under study (Denzin and Lincoln, 2008; Patton, 2002). Purposeful sampling was used to identify "information rich" research sites with the most relevant and interesting properties given the aim of the study (Patton, 2002). Accordingly, three Michigan cities representing geographically distinct areas of the state with high volumes of Food Assistance Program eligible recipients were selected for study. Within each city, two 
case study markets in early to midstages of development were identified, for a total of six case study farmers markets. Early to midstage markets (Andreatta and Wickliffe II, 2002; Lloyd et al., 1987) were selected for study as this sector represents the area of greatest growth potential for EBT programs in Michigan farmers markets.

A total of 32 farmers were interviewed at the six case study markets. In small markets with $<10$ vendors, census sampling was used. In markets with $\geq 10$ vendors, stratified random sampling (using a random number generator) was used to select participants with varying experience at each location: 1) farmers that had been participating in the farmers market for two years or more, 2) farmers that were new to the market that season, and 3 ) farmers that had participated in the market at one time but had since left. Farmers were defined as individuals who grow and sell edible crops for human consumption including, but not limited to, fruit, vegetables, meat, poultry, and dairy products. All farmers interviewed had experience with EBT at farmers markets.

In-depth interviews were conducted between Oct. 2010 and Apr. 2012 using a structured, open-ended interview guide [approved by the Social Science/Behavioral/Education Institutional Review Board at Michigan State University (IRB\# 10-495)]. Indepth interviews yield descriptive and explanatory data (Hesse-Biber and Leavy, 2006; Patton, 2002) and were chosen because of their strength in providing data based on first-hand knowledge, experience, and perceptions pertaining to the research questions posed. During these interviews, farmers were asked about the characteristics of their farm, farmers market participation, and participation in market EBT programs. Interviews lasted between 45 and $150 \mathrm{~min}$. In exchange for participating in the study, farmers were provided with a \$25 cash honorarium.

In-depth interviews were audio recorded and transcribed verbatim. A thematic coding system was developed to systematically identify recurring themes in the textual data (Patton, 2002). Codes are used to identify and extract text that serves as evidence for specific themes (Miles and Huberman, 1994). Thematic coding is particularly important in situations in which simple word searches are inadequate. In this study, it was particularly important since farmers often do not identify food assistance programs by their official names. Rather, they speak at length of their experience with a particular program but use incorrect program names or reference the program using attributes of the process used at the farmers market for redemption or reimbursement (e.g., the market tokens). In such situations, thematic coding is important as researchers can analyze the data based on respondents' descriptions of the EBT program rather than the (often incorrect) titles they used to identify the program. Codes were applied to the text from each data collection using QSR NVivo 9 (QSR International, Doncaster, Australia). Data were then extracted and summarized using displays. A display is a visual format that reduces the textual data and aids in identifying patterns and drawing valid conclusions (Miles and Huberman, 1994).

Table 1. Descriptive characteristics of farms regarding participation in Electronic Benefits Transfer (EBT) programs at Michigan farmers markets based on indepth interviews with 32 farmers representing 27 farms.

\begin{tabular}{|c|c|c|}
\hline$\underline{\text { Farm characteristic }}$ & $\begin{array}{l}\text { Respondents } \\
\text { (no.) }\end{array}$ & $\begin{array}{c}\text { Proportion of } \\
\text { respondents (\%) }\end{array}$ \\
\hline \multicolumn{3}{|l|}{ Area in production $(\text { acres })^{\mathrm{z}}$} \\
\hline$<1$ & 9 & 33 \\
\hline 1 to 5 & 10 & 37 \\
\hline 6 to 50 & 5 & 19 \\
\hline$>50$ & 3 & 11 \\
\hline \multicolumn{3}{|l|}{ Land ownership } \\
\hline Own & 16 & 59 \\
\hline Rent/lease/borrow & 3 & 11 \\
\hline Combination of own/rent/lease/borrow & 8 & 30 \\
\hline \multicolumn{3}{|l|}{ Products produced } \\
\hline Fruit and vegetables (produce) & 22 & 81 \\
\hline Meat and/or poultry & 3 & 11 \\
\hline Produce and meats & 2 & 8 \\
\hline \multicolumn{3}{|l|}{ Duration of farmers market experience (years) } \\
\hline$<5$ & 10 & 37 \\
\hline 5 to 10 & 8 & 30 \\
\hline$>10$ & 9 & 33 \\
\hline \multicolumn{3}{|l|}{ Total farmers markets attended (no.) } \\
\hline$<5$ & 15 & 56 \\
\hline 5 to 10 & 9 & 33 \\
\hline$>10$ & 3 & 11 \\
\hline \multicolumn{3}{|l|}{ Sales outlets } \\
\hline Farmers markets only & 6 & 22 \\
\hline $\begin{array}{l}\text { Farmers markets and other retail } \\
\text { or wholesale outlets }\end{array}$ & 21 & 78 \\
\hline \multicolumn{3}{|l|}{ Sales types } \\
\hline Producer-only, sell only what they produce & 16 & 59 \\
\hline Reseller, sell their products and other farmers & 11 & 41 \\
\hline
\end{tabular}

${ }^{\mathrm{z}} 1$ acre $=0.4047 \mathrm{ha}$

\section{Results}

Farmers represented a wide variety in agricultural experience, ranging in years of farming experience from production areas ranged from $400 \mathrm{ft}^{2}$ to 900 acres with $70 \%$ of the sample growing on less than five acres as prior research has shown is common for farmers market growers (Griffin and Frongillo, 2003). Farmers also showed a diversity of experience with farmers markets selling at one to 20 different farmers markets over a period of one to 64 years. Eighty-nine percent of the farmers interviewed sold horticultural products, primarily fresh fruit and vegetables. Farm characteristics are provided in Table 1.

Using a qualitative approach proved to be particularly important in this study because of the numerous inconsistencies in the language used to describe food assistance programs common at farmers markets. During the course of interviews with 32 farmers, they used 40 different terms to five to 70 years. In terms of scale, 
identify four major food assistance programs found in Michigan farmers markets. When referring specifically to SNAP EBT, farmers used 16 different terms to refer to the electronic technology, the federal or state program name, or the alternative redemption system used in the farmers market (Table 2). As stated above, analysis was based on descriptions of the EBT program as opposed to relying on the often incorrect terms farmers used to name the program.

Three main themes emerged during this research. First, based on their experiences with central terminal model EBT programs at farmers markets, the majority of farmers had a positive attitude regarding EBT. Second, many reasoned that their positive attitude emerged because the markets made the programs simple and convenient for them to participate in the redemption process. Third, some farmers believed that when a farmers market accepts food assistance benefits, it attracts new customers and thus expands the market's customer base.

Farmers interviewed had experience participating in central terminal model EBT programs at the case study farmers markets. Nevertheless their experience with these programs was not limited to the case study markets as farmers sold at one to 20 other markets, some of which had central terminal model EBT programs as well. The vast majority of farmers ( $85 \%)$ had positive comments about EBT programs at farmers markets. The remaining $15 \%$ were indifferent, meaning that they neither viewed the program negatively or positively. This minority of farmers all had production areas of two acres or less and indicated that EBT sales were not an important source of revenue for them.

For the $85 \%$ of farmers that viewed EBT programs positively, about half $(48 \%)$ explained that EBT sales were important as a source of revenue for them. With the market's EBT program, farmers said they were able to capture a small, but important portion of sales that they would not have access to otherwise. The remaining $52 \%$ of farmers spoke positively about EBT programs but did not identify a benefit that accrued to them personally. Rather, they stated that EBT and federal food assistance benefits were either important for the market or for the community where the market was located. Some stated that farmers markets should market to the needs of the surrounding community. For example, one farmer specifically commented that operating food assistance and EBT programs represented an "important philosophy of the market" and allowed the market to address community needs. Another farmer added that EBT programs at the market provided low-income community members who participate in the federal SNAP program the opportunity to use their benefits to buy fruit and vegetables. Overall, these farmers were pleased about their participation in a farmers market that had a real focus on improving food access in lower-income communities.

The second theme that emerged addressed the perceived convenience and simplicity of participating in central terminal model EBT programs. Nearly half $(45 \%)$ of farmers attributed their positive attitude about accepting EBT benefits to the way in which the farmers market(s) operated these programs. Farmers repeatedly emphasized that their main focus during market hours was on selling their products and attending to customers. Hence, without the current centralized EBT program in place at these markets, farmers suggested that the EBT redemption process would be too onerous to take on individually. The farmers who spoke positively about EBT program(s) identified specific ways in which the market(s) made it easy for them to accept SNAP benefits. Some expressed their relief that the market took care of the administrative work with USDA in turn making the process of redemption easy for them. Others referenced their hesitation to work with electronic devices or to split their time and attention between attending to customers and complying with the multiple steps required to redeem and accept a customer's benefits using EBT.

Generally, farmers agreed that having programs that were well administered and managed for them was critical. They indicated that they wanted a no-hassle system where they could depend on the market to manage the program as opposed to having a program that each vendor would have to manage individually. For instance, one farmer talked about the importance of having a strong market manager that understands growers and is timely and organized to manage food assistance programs on behalf of the farmers and vendors at the market. None of the farmers interviewed talked about central terminal model EBT programs as being cumbersome, difficult, or challenging. Rather, many made concise statements about the redemption processes, saying they "work great," are "very simple," or are "a piece of cake." One farmer specifically discussed his experience in multiple markets by saying he depends on the market to take care of the administrative aspects of completing USDA authorization paperwork, creating and administering an alternative redemption system in the market, and making the whole program as easy as possible for the vendors.

The third theme that emerged is that some farmers believed that accepting food assistance benefits at farmers markets attracts new customers, thereby expanding the market's customer base. A small but noteworthy minority (25\%) maintained that EBT shoppers would not attend the farmers market if they did not have the ability to use their SNAP benefits at the market. As one farmer stated, the EBT program "brings a different crowd of people down." Farmers, however, were mixed on the point of whether these programs generated repeat or regular shoppers. A few farmers even suggested that having the program helped to expose shoppers to new products that are more likely to be found at a farmers market. One farmer explained that they are not only seeing many lower-income shoppers at the market but "for maybe the first time in their life they are able to buy fresh, organic produce." Therefore, some farmers believed that the EBT program attracted new customers and also gave them the opportunity to purchase new items that they would not purchase under different circumstances.

Finally, at the end of each interview, farmers were asked about what they identify as most important for the survivability of farmers markets in low-income areas. Twenty-two percent of the farmers indicated that EBT programs and the acceptance of a wide variety of food assistance benefits were essential for the sustainability of farmers markets in low-income areas. In these instances, this was related to the third theme regarding the potential 
Table 2. Terms used by farmers when referring to Michigan farmers market Electronic Benefits Transfer (EBT) programs.

Reference

Electronic technology

Federal or State program name

Alternative redemption system
Terms used

EBT, Electronic Benefits Transfers, EBT card, EB cards or whatever, Bridge Card machine SNAP, food stamps, bridge cards, bridge program, benefits

Market tokens, wooden tokens, tokens, coins, bridge card money, laminated money for food assistance programs to expand a market's customer base. One farmer explained that accepting EBT attracted new market shoppers from the community saying "especially...the way the economy is right now, a lot of people are participating in programs the government is offering." Another farmer added that EBT programs at farmers markets help attract a new and diverse customer base, and also help keep a market successful.

\section{Discussion}

Although these results are reflective of Michigan markets, their applicability to other farmers and other regions may or may not hold. However, the themes that emerged provide insights into farmers perspectives that can be considered by farmers market management, state and federal policymakers, and other researchers interested in food assistance programming in a farmers market setting. In terms of market management, study results indicated that some farmers perceive central terminal model EBT programs as a method to bring new customers into the market thus expanding the market's customer base. Market managers operating farmers markets in low-income, urban areas may consider establishing centralized EBT programs in an effort to both attract new customers and expand the purchasing power of low-income shoppers who could use their food assistance benefits at the market. A strong customer base has been shown to influence vendor participation (Hofmann et al., 2009) and could be important for recruiting new vendors and retaining existing vendors. This is important as previous research has shown that the identification and recruitment of potential vendors are essential for the development and expansion of farmers markets (Govindasamy et al., 2003). When establishing a new EBT program, managers may also want to consider that the farmers in this case study viewed these programs positively when they were managed by the market, well administered, and overall very simple for vendors. These findings suggest that farmers markets that have the capacity necessary to manage these programs can be perceived by farmers to have important programs in place that influence the overall success of the market. As other studies have indicated, management is an important factor in successful farmers markets (Stephenson, 2008).

In terms of informing state and federal policymakers, these results demonstrated that the farmers who participated in this study generally viewed government-funded food assistance programs positively when managed by a third party, in this case the farmers market. Farmers acceptance of EBT programs in farmers markets is important to help USDA reach its goal to increase the number of farmers markets authorized to accept SNAP/EBT and SNAP redemptions at farmers markets (USDA, 2010b) and overall improve access to fresh, healthy foods. As program and policy changes are made to increase EBT at farmers markets, policymakers should take into consideration the need for market management capacity that farmers indicate as essential for making the central terminal model EBT programs run simply and effectively for them. Considering farmers perspectives, as this study did, is necessary for developing well-informed solutions.

Overall, this study indicated that participating farmers had a positive experience with central terminal EBT programs at Michigan farmers markets located in low-income, urban areas with high levels of SNAP distribution. Results suggest that EBT programs help expand a market's customer base, contributed to farmer revenues, and are perceived as important programs for market sustainability. Increasing SNAP redemptions at farmers markets should be viewed as both a public health intervention for low-income and underserved families (Buttenheim et al., 2012) as well as an opportunity for farmers and the horticultural industry to access a greater portion of SNAP benefits distributed each month.
The results from this study can provide a basis for future studies, both qualitative and quantitative. These findings offer a foundation for future research on this topic by identifying the variety of ways in which farmers refer to EBT programs (see Table 2). Development of future quantitative studies will unquestionably need to cogitate the lack of uniformity in language to gather reliable data. Additional research is necessary to understand farmers' attitudes regarding individual vendor-operated terminals for SNAP and other food assistance programs such as Women, Infants and Children and the federal Farmers Market Nutrition Program. Furthermore, future research should explore how EBT contributes to overall farmervendor profitability. Finally, to encourage greater adoption as is desired by USDA, research should explore the perceptions and preconceived notions of farmers who do not currently use EBT to better understand constraints and barriers.

\section{Literature cited}

Abel, J., J. Thomson, and A. Maretzki. 1999. Extension's role with farmers' markets: Working with farmers, consumers, and communities. J. Ext. 37(5). 12 Aug. 2012. <http://www.joe.org/joe/1999 october/index.php $>$.

Alkon, A. 2008. From value to values: Sustainable consumption at farmers markets. Agr. Human Values 25(4):487-498.

Andreatta, S. and W. Wickliffe, II. 2002. Managing farmer and consumer expectations. A study of a North Carolina farmers market. Hum. Organ. 61(2):167-176.

Anliker, J., M. Winne, and L. Drake. 1992. An evaluation of the Connecticut farmers' market coupon program. J. Nutr. Educ. 24(4):185-191.

Balsam, A., D. Webber, and B. Oehlke. 1994. The farmers' market coupon program for low-income elders. J. Nutr. Elder. 13(4):35-41.

Bell, J. and M. Standish. 2009. Building healthy communities through equitable food access. Community Dev. Investment Rev. 5(3):75-87. 
Buttenheim, A., J. Havassy, M. Fang, J. Glyn, and A. Karpyn. 2012. Increasing Supplemental Nutrition Assistance Program/Electronic Benefits Transfer sales at farmers' markets with vendor-operated wireless point-of-sale terminals. J. Acad. Nutr. Dietetics 112(5):636-641.

Denzin, N. and Y. Lincoln. 2008. Handbook of qualitative research. Sage Publ., Thousand Oaks, CA.

Dollahite, J., J. Nelson, E. Frongillo, and M. Griffin. 2005. Building community capacity through enhanced collaboration in the Farmers Market Nutrition Program. Agr. Human Values 22(3):339-354.

Fisher, A. 1999. Hot peppers and parking lot peaches: Evaluating farmers' markets in low income communities. 12 Aug. 2012 <http://www.foodsecurity.org/ HotPeppersPeaches.pdf>.

Flournoy, R. 2011. Healthy food, healthy communities: Promising strategies to improve access to fresh, healthy food and transform communities. 12 Aug. 2012. <http://www.policylink.org/site/apps/ nlnet $/$ content 2 aspx? $\mathrm{c}=\mathrm{lkIXLbMNJrE \& b=}$ 5136581 \&ct $=8020083>$.

Govindasamy, R., J. Italia, M. Zurbriggen, and F. Hossain. 2003. Producer satisfaction with returns from farmers' market related activity. Amer. J. Altern. Agr. 18(2): 80-86.

Griffin, M. and E. Frongillo. 2003. Experiences and perspectives of farmers from upstate New York farmers' markets. Agr. Human Values 20:189-203.

Hesse-Biber, S. and P. Leavy. 2006. The practice of qualitative research. Sage Publ., Thousand Oaks, CA.

Hofmann, C., J. Dennis, and M. Marshall. 2009. Factors influencing the growth of farmers' markets in Indiana. HortScience 44(3):712-716.

Just, R. and Q. Weninger. 1997. Economic evaluation of the Farmers'. Market Nutrition Program. Amer. J. Agr. Econ. 79:902-917.

Keeling-Bond, J., D. Thilmany, and C. Bond. 2009. What influences consumer choice of fresh produce purchase location? J. Agr. Appl. Econ. 41(1):61-74.
Lloyd, R., J. Nelson, and D. Tilley. 1987. Should I grow fruits and vegetables? Farmers' markets. Oklahoma State Univ. Ext. Facts No. 185:1-4.

Maxwell, J. 2012. Qualitative research design: An interactive approach. Sage Publ., Thousand Oaks, CA.

Michigan Farmers Market Association. 2012a. About us. 12 Aug. 2012. <http:// www.mifma.org/aboutus>.

Michigan Farmers Market Association. $2012 \mathrm{~b}$. Find a farmers market. 12 Aug. 2012. <http://www.mifma.org/find-afarmers-market $/>$.

Miles, M. and A. Huberman. 1994. Handbook of qualitative research. Sage Publ., Thousand Oaks, CA.

Mino, R. 2012. A look from inside: Market perspectives on the expansion of food assistance programs at Michigan farmers markets. Michigan State Univ., East Lansing, M.S. Thesis.

Montri, D., A. Segar, K. Chung, and R. Mino. 2011. Accepting Bridge Cards at Michigan farmers markets, 3rd ed. Michigan State Univ. Ext. Bul. E3163.

Patton, M. 2002. Qualitative research and evaluation methods. Sage Publ., Thousand Oaks, CA.

Pothukuchi, K. and B. Thomas. 2004. Food deserts and access to retail grocery in inner cities. Communities News Views 17(1):6-7.

Project for Public Spaces. 2003. Public markets and community-based food systems: Making them work in lower-income neighborhoods. Report prepared for the W.K. Kellogg Foundation. 12 Aug. 2012. <http://www.pps.org/pdf/kellogg report.pdf $>$.

Roper, N. 2012. SNAP redemptions at farmers markets exceed $\$ 11$ million in 2011. 12 Aug. 2012. <http://www.farmers marketcoalition.org/snap-redemptions-atfarmers-markets-exceed-11m-in-2011>.

Ross, N. 2006. How civic is it? Success stories in locally focused agriculture in Maine. Renewable Agr. Food Systems 21(2):114-123.

Segar, A. 2012. Bridging the gap: Between local food and Michigan families. $3^{\text {rd }}$ ed. 12 Aug. 2012. <http://www.mifma. org/food-assistance-partnership>.

State of Michigan. 2012. Green book report of key program statistics. 12 Aug. 2012. <http://www.michigan.gov/dhs/ 0,4562,7-124-5459_61179_7696_10830209273-,00.html .

Stephenson, G. 2008. Farmers' markets: Success, failure and management ecology. Cambria Press, Amherst, NY.

U.S. Department of Agriculture. 2009. Access to affordable and nutritious food Measuring and understanding food deserts and their consequences. 12 Aug. 2012. <http://www.ers.USDA.gov/ publications/ap-administrative-publication/ ap-036.aspx>

U.S. Department of Agriculture. 2010a. Supplemental Nutrition Assistance Program feasibility of implementing Electronic Benefit Transfer systems in farmers' markets. 12 Aug. 2012. <http:// www.fns.USDA.gov/snap/ebt/pdfs/ Kohl-Feasibility.pdf>.

U.S. Department of Agriculture. 2010b. Strategic plan FY 2010-2015. 12 Aug. 2012. <http://www.ocfo.USDA.gov/ USDA.sp/USDA.sp.htm>.

U.S. Department of Agriculture. 2012a. Farmers market growth: 1994-2011. 12 Aug. 2012. <http://www.ams.USDA. gov/farmersmarkets $>$.

U.S. Department of Agriculture. 2012b. Supplemental Nutrition Assistance Program participation and costs. 18 Oct. 2012. <http://www.fns.USDA.gov/ pd/snapmain.htm>.

U.S. Department of Agriculture. 2012c. Eligible food items. 18 Aug. 2012.<http:// www.fns.USDA.gov/snap/retailers/ eligible.htm>

Wasserman, W., D. Tropp, V. Lakins, C. Foley, M. DeNinno, J. Thompson, N. Owens, and K. Williams. 2010. Supplemental Nutrition Assistance Program (SNAP) at farmers markets: A how-to handbook. 12 Aug. 2012. <http://www. ams.USDA.gov/AMSv1.0/getfile?dDoc Name $=$ STELPRDC5085298 $>$.

Zepeda, L. and J. Li. 2006. Who buys local food? J. Food Distribution Res. 37:1-11. 